\title{
Diatoms of the Cymbella sensu lato species of the two different eco-regions of the Indian Mountain Rivers.
}

Jyoti Verma $^{1 *}$, Prakash Nautiyal ${ }^{2}$ and Prateek Srivastava ${ }^{3}$

${ }^{1}$ Department of Zoology, Allahabad of Allahabad, Allahabad 211002, U.P., India.

${ }^{2}$ Department of Zoology, H.N.B. Garhwal University, Srinagar, 246174, Uttarakhand, India.

${ }^{3}$ Amity Institute of Environmental Sciences, Amity University, Noida 201 303, India.

Received: 9/10/2017; Revised: 9/17/2017; Accepted: 9/21/2017

\begin{abstract}
This paper describes Cymbella sensu lato (Cymbopleura, Delicata, Encyonema, Encyonopsis and Reimeria) species from two different ecoregions of India. In the present study, twenty-six diatom taxa belonging to the genus Cymbella sensu lato were identified. In the flora nineteen species were recorded from the Vindhya region while eleven from the Himalaya. All of them were first records for the Vindhyan rivers. Seven taxa were new records for the Himalayan river.
\end{abstract}

Keywords: Central Highlands, diatoms, ecoregions, flora, India.

\section{Introduction}

The diatom classification in Round et al., (1990) placed five genera in the family Cymbellaceae: Placoneis Mereschkowsky, Cymbella Agardh, Brebissonia Grunow, Encyonema Kützing, and Gomphocymbella Müller. Since then a number of new genera have been proposed for inclusion in Cymbellaceae based largely on differences in valve shape and symmetry, areolae and raphe structure, and other features observed under the scanning electron microscope (SEM). These new genera include Afrocymbella Krammer (2003), Cymbellopsis Krammer (1997a), Cymbopleura Krammer (2003), Delicata Krammer (2003), Navicymbula Krammer (2003), and Oricymba Jüttner et al., (2010). In addition, to accommodate Encyonema-like taxa that are symmetric or nearly symmetric with respect to the apical axis, Krammer (1997a) erected the genus Encyonopsis with Navicula cesatii Rabenhorst as the type species. Recently, a total of 15 genera and many species have been included into the Cymbellaceae (Guiry and Guiry 2016).

The Indian mountain streams and its adjacent countries support a diverse diatom flora (at both species and generic levels), including several new, and rarely found, cymbelloid taxa Oricymba (Jüttner et al., 2010a), Cymbopleura, Cymbella (Jüttner et al., 2010b), Encyonema and Encyonopsis, some of which have unusual morphological features for their respective genera. In the present paper, we present an account of the Cymbella sansu lato species from the Yamuna drainage in the Himalaya and Central Highlands, Vindhya rivers in particular, and some locations on the Bhagirathi, Alaknanda and Ganga rivers and their tributaries.
Study Area

The part of Gangetic drainage considered in the study originates in the West Himalaya as the Yamuna and Ganga. While most of their tributaries arise in the Himalaya some arise in the Vindhya. The Vindhya rivers Ken and Paisuni join the lower part of the Yamuna before its confluence with the Ganga and Tons joins the Ganga little downstream of this confluence. Except for this connection with the Ganga R., these two regions vary in climate by virtue of their geographic location and geomorphology.

The Vindhya rivers selected for the study were located between $23^{\circ} 30^{\prime}$ to $26^{\circ} \mathrm{N}, 78^{\circ} 30^{\prime}$ to $82^{\circ} 30^{\prime} \mathrm{E}$ while in the west Himalaya between 29 $31^{\prime}$ to $31^{\circ} 20^{\prime} \mathrm{N}$ latitude, $77^{\circ} 33^{\prime}$ to $80^{\circ} 6^{\prime} \mathrm{E}$ longitude). The Vindhya rivers Ken, Paisuni and Tons flow north from low (north of Narmada, around Tropic of Cancer) to high latitude along southern fringe of the Indo-Gangetic Plains. The Ken and Tons were relatively larger drainage (300 to $350 \mathrm{~km}$ ) compared to the Paisuni $(100 \mathrm{~km})$ having an average gradient of $0.91 \mathrm{~m} \mathrm{~km}^{-1}, 2.0 \mathrm{~m} \mathrm{~km}^{-1}$ and $1.02 \mathrm{~m} \mathrm{~km}^{-1}$, respectively. The land is primarily used for agriculture along the banks of the Ken and the Tons River. Patches of forest (Shorea robusta) occur in case of the Ken River. In case of the Paisuni river the headwaters is covered by forest and only lower stretch of the river is used for agriculture. Except for the mouth zone these rivers vary topographically (Table 1).

\footnotetext{
*Corresponding Author:

Dr. Jyoti Verma,

Department of Zoology,

University of Allahabad, Allahabad, India.

E-mail: diatombuster@gmail.com
}

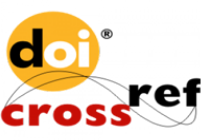

Page | 1705 
Table 1. Geographical co-ordinates of the sampling stations in different rivers of the Central Highland and Himalayan region.

\begin{tabular}{|c|c|c|c|c|c|c|}
\hline River system & $\begin{array}{c}\text { Rivers/ Stations with } \\
\text { acronym }\end{array}$ & $\begin{array}{l}\text { Latitude } \\
\text { (N) }\end{array}$ & $\begin{array}{l}\text { Longitude } \\
\text { (E) }\end{array}$ & $\begin{array}{l}\text { Altitude } \\
\text { (m asl) }\end{array}$ & $\begin{array}{l}\text { Distance } \\
\text { from } \\
\text { source } \\
(\mathrm{Km} .)\end{array}$ & Substrate \\
\hline \multirow{9}{*}{$\begin{array}{l}\text { Yamuna } \\
\text { (lower } \\
\text { stretch) }\end{array}$} & Ken River & & & & & \multirow{5}{*}{$\begin{array}{c}\mathrm{R}, \mathrm{P}-\mathrm{MB}, \mathrm{Cb}, \mathrm{Pb}, \mathrm{Si}, \mathrm{Cl} \\
-\mathrm{do}- \\
\mathrm{R}, \mathrm{Cb}, \mathrm{Pb}, \mathrm{Gr}, \mathrm{Sd}, \mathrm{Av} \\
\mathrm{Cl}\end{array}$} \\
\hline & Shahnagar K1 & $23^{\circ} 59^{\prime}$ & $80^{\circ} 15^{\prime} 45^{\prime \prime}$ & 400 & $\mathrm{ca} .10$ & \\
\hline & Panna K2 & $24^{\circ} 43^{\prime} 18^{\prime \prime}$ & $80^{\circ} 11^{\prime} 25^{\prime \prime}$ & 200 & 142.5 & \\
\hline & Banda K3 & $25^{\circ} 29^{\prime} 24^{\prime \prime}$ & $80^{\circ} 19^{\prime} 16^{\prime \prime}$ & 140 & 267.5 & \\
\hline & Chilla K4 & $25^{\circ} 46^{\prime} 54$ & $80^{\circ} 32^{\prime} 08^{\prime \prime}$ & 100 & 340 & \\
\hline & Paisuni River & & & & & \multirow{4}{*}{$\begin{array}{c}\text { R, P-B, Cb, Pb, Sd } \\
\text { R, P-B, Cb, Pb, Sd, Gr, } \\
\text { Si, Cl }\end{array}$} \\
\hline & Anusuya P1 & $25^{\circ} 08^{\prime} 14$ & $80^{\circ} 51^{\prime} 01^{\prime \prime}$ & 160 & 10 & \\
\hline & Chitrakut P2 & $25^{\circ} 13^{\prime} 54$ & $80^{\circ} 54^{\prime} 36^{\prime \prime}$ & 140 & 26 & \\
\hline & Purwa P3 & $25^{\circ} 16^{\prime} 17$ & $80^{\circ} 52^{\prime} 28^{\prime \prime}$ & 100 & 42 & \\
\hline Ganga & Tons River & & & & & \\
\hline (middle & Amdara T1 & $24^{\circ} 00^{\prime}$ & $80^{\circ} 26^{\prime} 21^{\prime \prime}$ & 400 & 20 & $\mathrm{Gr}, \mathrm{Si}, \mathrm{Cl}$ \\
\hline \multirow{3}{*}{ stretch) } & Maihar T2 & $24^{\circ} 16^{\prime} 35$ & $80^{\circ} 48^{\prime} 53^{\prime \prime}$ & 400 & 56 & $\mathrm{P}-\mathrm{B}, \mathrm{Cb}, \mathrm{Pb}, \mathrm{Gr}, \mathrm{Av}$ \\
\hline & Satna T3 & $24^{\circ} 34^{\prime} 07$ & $80^{\circ} 54^{\prime} 36^{\prime \prime}$ & 323 & 98 & Av \\
\hline & Chakghat T4 & $25^{\circ} 03^{\prime} 28$ & $81^{\circ} 42$ '21”' & 100 & 232.5 & $\mathrm{P}-\mathrm{B}, \mathrm{Cb}, \mathrm{Pb}, \mathrm{Gr}, \mathrm{Av}$ \\
\hline \multirow{2}{*}{$\begin{array}{l}\text { Yamuna } \\
\text { (upper } \\
\text { stretch) }\end{array}$} & Supin (Tons) $\mathrm{S}$ & $31^{\circ} 45^{\prime} 2^{\prime \prime}$ & $78^{\circ} 10^{\prime} 29^{\prime \prime}$ & 1500 & 60 & $\mathrm{MB}, \mathrm{Cb}$ \\
\hline & Yamuna Y & $30^{\circ} 55^{\prime} 35^{\prime \prime}$ & $78^{\circ} 23$ '8”' & 1800 & 70 & Large \& small B \\
\hline \multirow{7}{*}{$\begin{array}{l}\text { Bhagirathi } \\
\text { (middle } \\
\text { stretch) } \\
\text { Ganga } \\
\text { (foothill) }\end{array}$} & Dharasu D & $30^{\circ} 37^{\prime} 17^{\prime \prime}$ & $78^{\circ} 1917$ & 800 & 120 & $\mathrm{Cb}, \mathrm{Pb}, \mathrm{Gr}$ \\
\hline & Bhagirathi B & $30^{\circ} 24^{\prime} 48^{\prime \prime}$ & $78^{\circ} 27^{\prime} 25^{\prime \prime}$ & 620 & 150 & $\mathrm{~B}, \mathrm{Cb}, \mathrm{Pb}, \mathrm{Si}$ \\
\hline & Nagni $\mathbf{N}$ & & & & & \\
\hline & Khiret N1 & $30^{\circ} 23^{\prime} 25^{\prime \prime}$ & 78॰19’30” & 2200 & 16 & P-MB \\
\hline & Nagni N2 & $30^{\circ} 19^{\prime} 15^{\prime \prime}$ & $78^{\circ} 21^{\prime} 10^{\prime \prime}$ & 1400 & 79 & $\mathrm{~B}, \mathrm{Cb}$ \\
\hline & Jajal N3 & $30^{\circ} 18^{\prime} 15^{\prime \prime}$ & 78 ॰20’40”' & 1200 & 98 & $\mathrm{Cb}, \mathrm{Pb}, \mathrm{Gr}$ \\
\hline & Shivpuri N4 & $30^{\circ} 8 ’ 15^{\prime \prime}$ & $78^{\circ} 23 ’ 30^{\prime \prime}$ & 375 & 142 & $\mathrm{~B}, \mathrm{Cb}, \mathrm{Pb}, \mathrm{Gr}, \mathrm{Si}$ \\
\hline $\begin{array}{l}\text { Alaknanda } \\
\text { (middle } \\
\text { stretch) }\end{array}$ & Alaknanda A & $30^{\circ} 13^{\prime} 10^{\prime \prime}$ & 78 ॰48’32”' & 550 & 150 & $\mathrm{~B}, \mathrm{Cb}, \mathrm{Pb}, \mathrm{Gr}, \mathrm{Si}$ \\
\hline
\end{tabular}

The Himalaya streams Dharasu and Nagni Gad and rivers Supin-Tons, Yamuna, Bhagirathi and Alaknanda flow in southerly direction. The latter two are the parent Mountain Rivers forming the Ganga R. The Dharasu and Nagni Gad are right bank tributaries of the Bhagirathi (ca. $40 \mathrm{~km}$ upstream of Tehri) and Ganga (downstream of Devprayag). The Supin, a parent tributary of the Tons which along with the Giri R. forms the western limit of the Yamuna watershed and thus the Gangetic drainage. There was relatively more forest cover (Cedrus deodara, Quercus spp.) in the Yamuna system and Nagni Gad, than the Bhagirathi and Alaknanda (Pine on hill tops) where most of the slopes below $1100-1500 \mathrm{~m}$ asl have scrub. The gradient ranges from 15 to $2.0 \mathrm{~m} \mathrm{~km}^{-1}$.

\section{Materials and Methods}

Sampling: Diatom collections were obtained from 20 stations; 11 stations on 3 rivers in the Vindhya region and 9 stations on 3 rivers and 2 streams in the Himalaya seasonally in 2007. The samples were replicated at each station. Diatom samples were collected by scraping the cobble surface with a brush. The scrapings were transferred to storage vials and preserved in $4 \%$ formalin for further processing. The formalin preserved samples were first cleaned with double distilled water to remove traces of formaldehyde. Samples were given Hydrochloric acid- peroxide treatment, washed repeatedly and mounted in Naphrax. Two slides were prepared for each sample. Each slide was examined under bright field in a BX-40 Trinocular Olympus microscope with x100 oil immersion objective to identify the species. Images were obtained by NIKON Digital Imaging System and processed with ADOBE PHOTOSHOP software to prepare photographic plates of the flora at x1500.

Identifications were made according to standard literature Krammer (1982a, b, 1997a, b, 2002, 2003) Taxonomy of our research along with the data list published for the last century was adopted under a modern classification system (Fourtainer and Kociolek 2011, Guiry and Guiry 2016). The dimensions and distribution of the species were separately indicated for each species. Species and intraspecific taxa are arranged alphabetically in the text and plates. were also consulted. The permanent mounts have been adequately stored at the Aquatic Biodiversity Unit, Department of Zoology, H. N. B. Garhwal University, Srinagar, Uttarakhand, India.

The diatoms were identified according to Krammer (1982a, b, 1997a, b, 2002, 2003) Krammer \& LangeBertalot (1986). The dimensions and distribution of the species were separately indicated for each species. Species and infraspecific taxa are arranged in the text and plates. 


\section{Results}

1. Cymbopleura angustata Krammer 2003 (Figs. 102: 17; 105: 9-17b; 109: 12-16). Length (L) 23-26, Width (W) 5-6, Striae (S) 18-20, Rhomboidlanceolate, ends produced and narrowly capitate, axial area narrow, linear, central area small, raphe slightly lateral, striae radiate throughout (Plate 1, Fig. 1).

2. C. angustata var spitsbergensis Krammer 2003 (Figs. 106: 11-20). L $22 \mu \mathrm{m}, \mathrm{W} 6 \mu \mathrm{m}, \mathrm{S} 17-18 / 10 \mu \mathrm{m}$, very small lanceolate forms, body symmetrical lanceolate, ends subcapitate to capitate (Plate 1, Fig. 2).

3. C. citrus (Catrter and Bailey-Watts) Krammer 2003 (Figs. 97: 5-12). L 16-26, W 7.4-9.6, S 12-13, broadly sub elliptic-lanceolate, dorsal and ventral margins strongly arched, ends slightly apiculate. Maximum L/B ratio 2.9. Axial area narrow, linear, central area asymmetric, raphe filiform to slightly lateral, striae slightly radiate throughout, puncta 33-36/10 $\mu \mathrm{m}$ (Plate 1, Fig. 3).

4. C. cf. hergnica (A. Schmidt) Krammer 2003 (Figs.

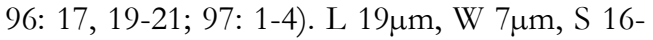
$18 / 10 \mu \mathrm{m}$ Valve slightly dorsiventral, broadly sub-elliptical to elliptical-lanceolate, dorsal margin strongly, axial area narrow, ventral margin slightly arched, striae radiate throughout, striae in the middle portion (Plate 1, Fig. 4).

5. C. diminuta (Grunow) Krammer 2003 (Figs. 127: 1-10). L 15-27, W 5-6, S 15-16, Lanceolateelliptical, dorsal margin convex, ventral nearly straight, ends tapering to rounded, axial area narrow, slightly ventrally displaced, central area indistinct. Raphe filiform, curved. Striae very slightly radiate in the middle portion. Puncta 28-30/10 (Plate 1, Fig. 5).

6. C. kuelbsii Krammer 2003 (Figs. 113: 1-7b; 127: 11, 12, 19, 20-27). L 23-37, W 6-8.5, S 10-13, Lanceolate, dorsal and ventral margins similarly arched, ends rounded. Axial areas narrow, especially towards the ends, almost in median line of the valve, central area unilateral. Raphe filiform to slightly lateral. Striae barely radiate, indistinctly punctate, puncta 23-28/10 $\mu \mathrm{m}$ (Plate 1, Fig. 6)

7. C. Kuelbsii var. nonfasciata Krammer 2003, (Figs. 127: 20-27). L 20-25, W 6-7.5, S 11-16, Lanceolate, arched dorsally, ends sharply rounded, striae parallel (Plate 1, Fig. 7).

8. C. laponica (Grunow) Krammer 2003 (Figs. 137: 12-17). L 48-54, W 7-8, S 21-22, Rhomboidlanceolate, gradually tapering from the middle to the acute, slightly apiculate protracted ends, short ends, sharp, set off, axial area narrow linear, central area rather large, striae radiate throughout, puncta delicate (Plate 1, Fig. 8).

9. C. anglica Krammer 2003 (Figs. 76: 1-13; 77: 1-13; 781-8; 79;1-14; 8012; 821-12; 839-11). L 26-45, W 9-12, S 12-14, Elliptical-lanceolate, valves moderately dorsiventral, ventral margin slightly arched, slightly convex in the middle portion. Ends produced rostrate sub-capitate, axial area narrow, raphe lateral, striae radiate throughout, on the dorsal side of the central area irregularly arranged, puncta 27-33/10 $\mu \mathrm{m}$ (Plate 1, Fig. 9).

10. C. rupicola (Grunow) Krammer 2003, (Figs. 66: 1-17; 67: 1-18). L 20-40, W 7-10, S 12-16, Rhomboid-lanceolate, dorsal and ventral margins continuously arched or ventral margin barely arched, ends are narrowly rounded, only subtly set off from the valve body, axial area narrow, linear, widening towards central area, central area only a slight central widening. Raphe slightly lateral, curved, narrowing towards the both ends and slightly reverselateral towards the proximal ends. Striae radiate throughout (Plate 1, Figs. 10).

11. C. cf. subaequalis var. subaequalis (Grunow) Krammer 2003 (Figs. 199: 1-15). Length 28$32 \mu \mathrm{m}$, width $9-11 \mu \mathrm{m}$, striae 9-12/10 $\mu \mathrm{m}$ (Plate 1, Fig. 11).

12. Encyonopsis subminuta Krammer \& Reichardt Krammer 1997b (Fig. 144: 1-2). L 12-18, W 45, S 11-13, Elliptic, dorsal and ventral margins slightly arched, tapering to small, ends narrowly capitate, axial area narrow, central area lacking or not well expressed, raphe filiform, striae radiate throughout (Plate 1, Figs. 12-13).

13. C. vrana Lange-Bertalot and Krammer 2003 (Figs. 93: 9-18). L 20-34, W 8-9.4, S 12-13, Lanceolate, dorsal margin more arched than the ventral one, ends apiculate, protracted, axial area moderately wide, linear, narrowing slightly towards the ends, almost in the median line of the valve. Central area very small, irregular, asymmetric space. Raphe barely lateral, narrowing towards the proximal and distal ends. Striae slightly radiate throughout, irregularly arranged around the central nodule (Plate 1, Fig. 14).

14. Delicata sparsistriata var. cf. parva Krammer 2003 (Figs. 132: 21-33). L 19-25, W 4.5-5.3, S 12-14, Lanceolate, valves slightly dorsiventral, ends slightly or not produced and narrowely rounded, axial area narrow, barely ventrally displaced, linear, raphae filliform, striae slightly radiate, puncta 25-30/10 $\mu \mathrm{m}$ (Plate 1, Figs. 16).

15. Encyonema jemtlandicum var. venezolanum Krammer, Metzeltin et al., 2005 (p. 129, Figs. 18, 16). L 30-39, W 8.5-10, S 10-13, Semielliptical, dorsal valve strongly convex and ventral side almost straight, ends not set off, raphe straight and eccentric, isolated stigma on the middle of the dorsal striae, striae almost parallel (Plate 1, Figs. 17-18).

16. E. minutum (Hilse ex Rabenhorst) 1862 (Figs. 119: 1-13; 164). L 12-20, W 4-6, S 12-14, Semielliptical, smaller forms, ends not set off, or only slightly so, partially curved a little towards the ventral side, one stigma on the dorsal striae (Plate 1, Figs. 19-20). 
17. E. perminutum Krammer Metzeltin et al., 2005 (Figs. 6-15). L 22-24, W 6-7, S 13-14, Semielliptical, smaller forms, dorsal valve strongly convex and ventral side almost straight, one stigma on the dorsal side, raphae straight, striae almost parallel (Plate 1, Fig. 21).

18. E. silesiacum [Bleisch in Rabenhorst] 1864 (Figs. 117: 1-24). L 20-30, W 8-12, S 12-16, Semielliptical to semilanceolate, valve crescent shaped, dorsal valve strongly convex and ventral side almost straight, raphe strongly displaced to the ventral side, two stigmas on the dorsal striae (Plate 1, Fig. 22).

19. E. vulgare Krammer var. vulgare Metzeltin et al., 2005 (Figs. 10-12; p. 128, Figs. 5-11). L 67-72, W 12-13, S 9, Semielliptical, dorsal valve convex and ventral side straight to somewhat convex in middle, striae straight to radiate (Plate 1, Fig. 23).

20. Encyonema spp. Length $16-21 \mu \mathrm{m}$, width $7-8 \mu \mathrm{m}$, striae 10-11/10 $\mu \mathrm{m}$ (Plate 1, Figs. 24-25).

21. Encyonopsis krammeri Reichardt (Krammer 1997, p. 99, figs 144: 12-15). Length 17-22 $\mu \mathrm{m}$, width 5-6 $\mu \mathrm{m}$, striae $18-20 / 10 \mu \mathrm{m}$ Valves weakly dorsiventral, both dorsal and ventral margin convex. Apices protracted, capitate, narrow rounded, slightly ventrally deflected. Axial area linear, narrow. Central area absent. Raphe weakly lateral, proximal and distal portions filiform. Polar (distal) raphe endings first dorsally then ventrally deflected. Striae weakly radial in the central region becoming strongly radial towards the apices. (Plate 1, Fig. 15).

22. Encyonopsis leei Krammer 2003 (Figs. 162: 4-11; 15-19). L 19-25, W 7-7.5, S 8-9, Elliptical, valves nearly symmetrical, dorsal and ventral margins slightly convex, ends broadly rounded. Axial area narrow, linear, central area small, formed by shortening or lacking of some central dorsal striae. Raphe filiform, curved, terminal fissures ventrally bent. Striae in the middle portion parallel slightly radiate at the ends, puncta 21-29/10 $\mu \mathrm{m}$ (Plate 1, Figs. 2627).

23. E. leei var. leei Krammer 2003 (Figs. 162: 1519). L 22-25, W 7-8, S 8-9 Elliptical, striae more coarsely punctate, $22-23$ puncta/10 $\mu \mathrm{m}$ (Plate 1, Fig. 28)

24. E. Leei var. sinensis Metzeltin and Krammer, Krammer 2003 (Figs. 162: 4-11). L 23-29, W 7 8, S 8 Elliptical, striae finely punctate, 26-27 puncta/10 $\mu \mathrm{m}$ (Plate 1, Fig. 29).

25. Reimeria sinuata (Gregory) Kociolek \& Stoermer, Metzeltin et al., 2005 (Figs. 148: 1017). L 10-16, W 3.5-5, S 9-11, Lanceolate, valve asymmetrically linear, with broadly rounded apices, ventral margin slightly concave with gibbous midvalve, dorsal margin convex, linear, central area small formed by lack of striae, ventral isolated punctum, striae nearly parallel (Plate 1, Figs. 30-31).
26. R. uniseriata Sala, Guerrero and Ferrario, Metzeltin et al., 2005 (Figs. 1-13). L 14-16, W 3.5-4.5, S 8-10, Lanceolate, valve asymmetrically linear, broadly rounded apices, ventral margin slightly undulated with slightly gibbous midvalve, dorsal margin convex, linear, central area small, formed by shortening or lacking of some central striae, ventral isolated punctum, striae parallel to radiate (Plate 1, Fig. 32).

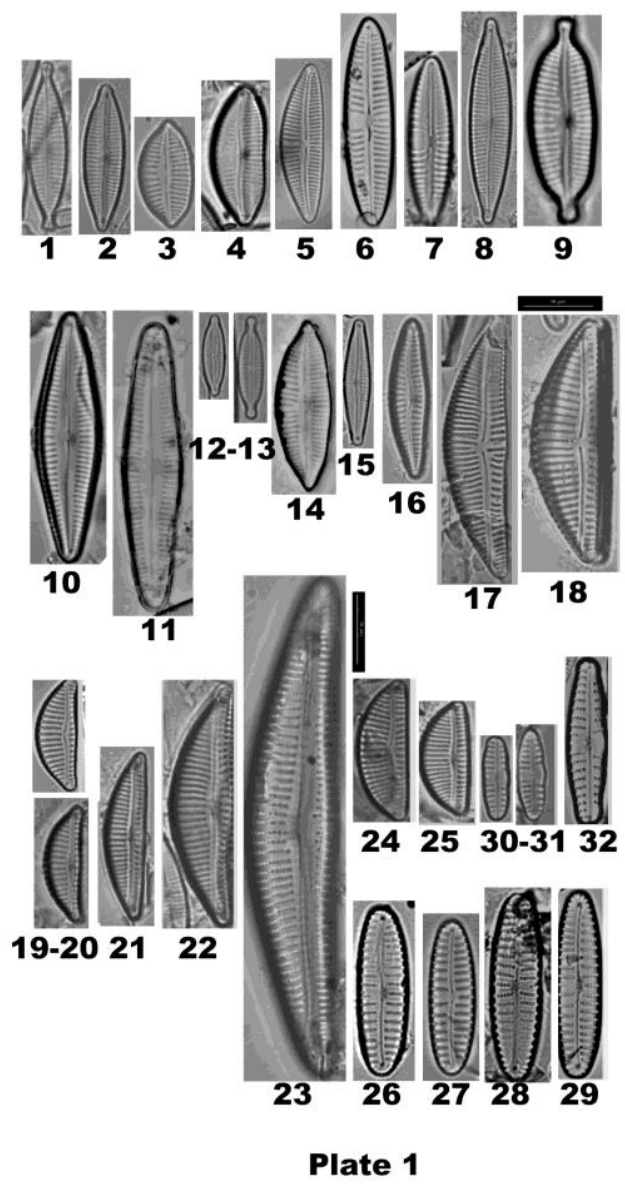

\section{Discussion}

Twenty six diatom taxa belonging to the genus Cymbella sensu lato (Cymbopleura, Delicata, Encyonema, Encyonopsis and Reimeria) were recorded, nineteen from the Vindhya region and eleven from the Himalaya. Four taxa (Delicata sparsistriata v. parva, Encyonema jemtlandicum v. venezolanum, E. minutum, E. silesiacum) were common to both the ecoregions. Seven taxa (Cymbopleura diminuta, C. cf. hercynicum, Delicata sparsistriata var. parva, Enchyonema jemtlandicum var. venezolanum, Enchyonopsis leei, E. leei var. leei, Reimeria uniseriata) were new records from the Himalayan region. Twenty four Cymbella sensu lato taxa are known from fourty six sites in the Himalaya (Nautiyal et al., 2004 a \& b). Now, the Himalayan region has thirty one taxa (7 present + 24 earlier) from 55 sites belonging to Cymbella sensu lato. The Vindhya region seems to be richer in 
Cymbella sensu lato as 19 taxa were obtained from 11 sites.

There is limited investigation of freshwater diatoms in South East Asia. Among species of the genus Cymbella, 49 were reported from northeastern China (Fan et al., 1993, Bao et al., 1992), 44 from India (Jena et al., 2006, Nautiyal et al., 2004 a \& b), and 9 from Japan (Hirano 1972). In the Himalayan region, 4 new species of Cymbella from alpine lakes and springs have been reported from Everest National Park of Nepal (Juttner et al., 2010, 2000). There were also studies on cymbelloid diatoms near Mount Everest in China (Li et al., 2007b), showing that 44 species belong to Cymbella, of them 16 new records, some of them unique to this region. One new species of Cymbella has been found from northwest Tibet (Li et al., 2003a), and one from the Far East (Lee et al., 1993), respectively. One Cymbella species was found that is unique to this area ( $\mathrm{Li}$ et al., 2007a), and some taxa belonging to Cymbella are found that have different morphological features compared with previously published descriptions (Li et al., 2003c).

Considering the distribution of the species in this study, Cymbopleura angusta, E. minutum, E. silesiacum, Reimeria sinuata, Reimeria uniseriata were the most common diatom species in mountain freshwater ecosystems and it is tolerant to high levels of eutrophication (Kelly \& Whitton 1995, Gosselain et al., 2005). It has been reported from many different parts of the world, for instance Australia (Foged 1978), Europe (Krammer \& Lange-Bertalot 1986), Japan (Kawashima \& Mayama 2001), Siberia (Lange-Bertalot \& Genkal 1998), South America (Metzeltin et al., 2005) and the United States (Patrick \& Reimer 1975).

The diversity of diatoms in the Indian biogeographic region is relatively low compared to the world record and there are several reasons why the taxa have not been recorded in India. Some species are probably confused to the morphologically similar taxa. So, the samples would be investigated attentionally.

\section{Acknowledgement}

The academic support by the Heads, Department of Zoology, H.N.B. Garhwal University and University of Allahabad, is acknowledged. JV thanks K. R. Singh for procuring the diatom samples from remote places in the river basin.

\section{References}

1. Anand VK, Kant S, Diatoms of Jammu Mansar lake, Geobios 3 1976: 132-133.

2. Bao W, Wang Q, Reimer CW, "Diatoms from the Changbaishan mountain area (In Chinese)". Bulletin of Botanical Research 12 1992: 125-143.
3. Dickie $G$, Notes on algae from the Himalayas. J of Lin Soc of Bot 1882, 19, 230-232.

4. Fan Y, Wang Q, Bao W, Investigation on Cymbellaceae from northeastern China (In Chinese). Natural Sciences J of Harbin Normal University, 1993, 9, 82-106.

5. Gandhi HP, Fresh water Diatoms of Central Gujarat (with a review and some others). Bishen Pal Singh Mahendra Pal Singh Dehradun, 1998, 313 pp.

6. Ghosh M, Gaur JP, Structure and interrelation of epilithic algal communities in two deforested streams at Shillong India. Archives für Hydrobiologia, 1991, 122, 105-116.

7. Hustedt F, Die Diatomeen Flora einiger Hochgebirgseen der Landschaft Davos in den Schwizer Alpen. International Reviews Hydrbiologie und Hydrographie, 1943, 43(2-4), 225280.

8. Hustedt F, Die Kieselalgen Deutschlands Oesterrichs und der Schweiz Bd. 7 Teil 2 Translated by N. G. Jensen as The Pennate Diatoms 1985 Koeltz Scientific Books Koenigstein, 1931-1959, 918 pp.

9. Jena M, Ratha S K, Adhikary SP, Diatoms (Bacillariophyceae) from Orissa State and Neighbouring Regions India. Algae, 2006, 21, 377-392.

10. Jüttner I, Gurung S, Sharma C, Sharma S, Morphology of new taxa in the Cymbella aspera and Cymbella neocistula groups Cymbella yakii sp. nov. and Cymbella cf. hantzschiana from Everest National Park Nepal. Polish Bot J, 2010, 55: 73-92.

11. Jüttner I, Cox EJ, Ormerod SJ, New or poorly known diatoms from Himalayan streams. Diatom Research, 2000, 15, 237-262.

12. Kant S, Vohra S, Algal flora of Jammu and Kashmir state. J Ind Bot Soc, 1997, 78, 51-64.

13. Khan M A, Phycological studies in Kashmir: Algal biodiversity. In: A. Kumar (ed.) Ethology of Aquatic Biota. APHA Publication Corporation New Delhi, 2002, pp. 69-93

14. Krammer K, Die cymbelloiden Diatomeen: Eine Monographie der weltweit bekannten Taxa. Teil 1. Allgemeines und Encyonema Part. - In: Lange-Bertalot H. P. Kociolek (eds.): Biblioth. Diatomol. 1997a, 36, 1382. J. Cramer Berlin.

15. Krammer K, Lange-Bertalot H, Bacillariophyceae. Die Süsswasserflora von Mitteleuropa. Vol. 2/1 Naviculaceae p. 1-876 mit 206 pl. Vol. 2/2 Bacillariaceae Epithemiaceae Surirellaceae p. 1-596 (1988). Vol 2/3 Centrales Fragilariaceae Eunotiaceae p. 1-576 (1991). Vol. 2/4 Achnanthaceae Kritische Erganzungen zu Navicula (Lineolatae) und Gomphonema. p.1-437 (1991). Vol. 5 English and French translations of the keys and supplements (2000). Stuttgart and Heidelberg.

16. Krammer K, Lange-Bertalot H, Bacillariophyceae. Teil 2. In: Süsswasser Flora von Mitteleuropa Band 2/2 Bacillariaceae Epithemiaceae Surirellaceae. (H. Ettl J. Gerloff H. Heyning and D. Mollenhauer eds.) 1999a, 611 pp. 184 pl. Spektrum Akademischer Verlag Heidelberg Berlin.

17. Krammer K, Lange-Bertalot H, Bacillariophyceae. Teil 4. In: Süsswasser Flora von Mitteleuropa Band 2/4. Achnanthaceae 4 (H. Ettl J. Gerloff H. Heyning and D. Mollenhauer eds.) 68 pp. 88 pl. Spektrum Akademischer Verlag Heidelberg Berlin. 
18. Krammer K. (2002). Diatoms of Europe. Diatoms of European Inland waters and comparable habitats. $(\mathrm{H}$. Lange-Bertalot eds.)- Vol 3 The genus Cymbella, 2004, 584 pp. 194 pl. A. R. G. Gantner and Verlag K. G FAL 94191 Ruggell.

19. Krammer K, Diatoms of Europe. Diatoms of European Inland waters and comparable habitats (H. Lange-Bertalot ed.) Vol 4. The genus Cymbopleura Delicata Navicymbula Gomphocymbellopsis and Afrocymbella, 2003, 530 pp. 164 pl. A. R. G. Gantner Verlag K. G. FAL 94191 Ruggell.

20. Lange-Bertalot H, Diatoms of Europe. Diatoms of European Inland waters and comparable habitats. - Vol 2 Navicula sensu stricto - 10 genera separated from Navicula sensu lato - Frustulia, 2001, 526 pp. 140 pl. A. R. G. Gantner and K. G. Verlag FAL 94191 Ruggell.

21. Lange-Bertalot $\mathrm{H}$, Cavacini $\mathrm{P}$, Tagliaventi N, Alfinito S, Diatoms of Sardina. Biogeography-Ecology-Taxonomy Iconographia Diatomologica 12 A. R. G. Gantner and K. G. Verlag (eds.), 2003, 438 pp. 137 plates.

22. Lee JH, Gotoh T, Chung J, Cymbella orientalis sp. nov. a freshwater diatom from the Far East. Diatom Research, 1993, 8, 99-108.

23. Li Y, Gong Z, Shen J, Freshwater diatoms of eight lakes in the Yunnan Plateau China. Journal of Freshwater Ecology, 2007a, 22, 169-171.

24. Li Y, Gong Z, Xie P, Shen J, Floral survey of the diatom genera Cymbella and Gomphonema (Cymbellales Bacillariophyta) from the Jolmolungma Mountain region of China. Cryptogamie Algologie, 2007b, 28, 209-244.

25. Li J, Wei L, Zheng M, A new sepceis of Cymbella agardh (Bacillariophyta) from northwest Xizang (Tibet) and its microstructure. Acta Micropalaeontologica Sinica, 2003a, 21, 435-438.

26. Li Y, Xie P, Gong Z, Shi Z, Gomphonemaceae and Cymbellaceae (Bacillariophyta) from Hengduan Mountains region (Southwest China). Nova Hedwigia, 2003c, 76, 307-336.

27. Metzeltin D, Lange-Bertalot H, Diatoms from the Island Continent Madagascar. Annotated Diatom Micrographs (H. Lange-Bertalot ed.). Iconographia Diatomologica 11 A. R. G. Gantner Verlag K. G., 2002.

28. Metzeltin D, Lange-Bertalot H, Garcia-Rodriguez F. Diatoms of Uruguay. Taxonomy-Biogeography Diversity. Annotated Diatom Micrographs (H. LangeBertalot ed.) Iconographia Diatomologica 15 A. R. G. Gantner Verlag K. G. 2005 pp. 726240 plates.

29. Nautiyal P, Kala K, Nautiyal R, A preliminary study of the diversity of diatoms in streams of the Mandakini basin Garhwal Himalaya. In: Proceedings of $17^{\text {th }}$ International Diatom Symposium Ottawa 2002 August 25-31 (M. Poulin ed.) Biopress Bristol, 2004b, pp. 235-269.
30. Nautival P, Nautiyal R, Kala K, Verma J, Taxonomic richness in the diatom flora of Himalayan streams (Garhwal India). Diatom, 2004a, 20: 123-132.

31. Prasad BN, Srivastava BN, Fresh water algal flora of Andaman and Nicobar Islands. Bishen Singh Mahendra Pal Singh Dehradun, 1992, 369 pp.

32. Rao SD, A botanical tour in the Sikkim State Eastern Himalayas. Bulletin Botanical Survey of India, 1963, 5(2): 165205.

33. Round FE, RM Crawford, DG Mann The Diatoms: Biology Morphology of the Genera. Cambridge University Press Cambridge, 1990.

34. Rout J, Gaur JP, Composition of dynamics of epilithic algae in a forest stream at Shillong (India). Hydrobiologia, 1994, 291: 61-74.

35. Sarode PT, Kamat ND, Fresh Water Diatoms of Maharashtra. Saikripa Prakashan Aurangabad India, 1994, 338 pp.

36. Saxena PN, Algal flora of Usar lands in Uttar Pradesh Science and Culture, 1960, 25(9): 542-543.

37. Schmidt A (1874-1959). Atlas der Diatomaceen-Kunde. Heft 1-120 Tafeln 1-480 (Tafeln 1-216 A Schmidt; 213 216 M Schmidt; 217-240 F. Fricke; 241-244 H. Heiden; 245-246 O Muller; 247-256 F. Fricke ; 257-264 H Heiden; 265-268 F. Fricke; 269-472 F Hustedt). Aschersleben Leipzig.

38. Schmidt A, Atlas der Diatomaceenkunde. Herausgegeben von Friedrich Hustedt Bremen, 1913, Tafel 297-306.

39. Singh CS, A systematic account of the fresh water diatoms of Uttar Pradesh-I. In: Proceedings National Institute of Science India, 1963, 29(B), 622-631

40. Sinha B.D. Srivastava N.K, Algal flora of Balmikinagar Bihar. Phykos, 1980, 19(2): 171-174.

41. Verma J, Biodiversity patterns of lotic (fresh water) diatoms in mountain chains (North India). D. Phil. Thesis University of Allahabad Allahabad, 2009, 220 pp.

42. Werum M, Lange-Bertalot $\mathrm{H}$, Diatoms in springs from Central Europe and elsewhere under the influence of hydrogeology and anthropogenic impacts. EcologyHydrogeology- Taxonomy (H. Lange-Bertalot ed.), 2004 pp. 480. Iconographia Diatomologica 13 A. R. G Gantner Verlag K. G.

\section{Cite this article as:}

Jyoti Verma and Prakash Nautiyal1 and Prateek Srivastava. Diatoms of the Cymbella sensu lato species of the two different Eco-regions of the Indian Mountain Rivers. Annals of Plant Sciences 6.10 (2017) pp. 1705-1710

doi: http://dx.doi.org/10.21746/aps.2017.10.4 